\title{
Past and projected future changes in moisture conditions in the Canadian boreal forest
}

\author{
by Yonghe Wang ${ }^{1}, *$, Edward H. Hogg ${ }^{1}$, David T. Price ${ }^{1}$, Jason Edwards ${ }^{1}$ and Tim Williamson ${ }^{1}$
}

\begin{abstract}
Spatial data for the Climate Moisture Index and the Palmer Drought Severity Index were generated from gridded temperature and precipitation data for the Canadian boreal zone over the period 1951-2010. Annual values for the indices for 2011-2100 were generated from projections of future climate derived from four general circulation models forced by three greenhouse gas emissions scenarios. Linear regression models between the indices and time were fitted to examine long-term trends. Results indicated that several large regions of the Canadian boreal forest experienced substantial drying during 1951-2010. Future projections indicated a general trend toward drier conditions during the $21^{\text {st }}$ century. Overall, the analysis indicated more frequent and/or more severe droughts across managed western and central portions of the boreal forest in coming decades. These projections of indices are relevant to forest management because soil moisture availability is an important determinant of forest distribution, tree health, and regeneration success. Knowledge of the range of potential future changes in drought occurrence and intensity will aid forest managers and decisionmakers in incorporating climate change considerations into forest management planning and practices.
\end{abstract}

Keywords: climate change impacts, adaptation, forest management planning, forest management practices, uncertainty, scenario approach, general circulation models, greenhouse gas, Climate Moisture Index, Palmer Drought Severity Index, boreal forest

\section{RESUME}

Des données géospatiales de l'indice d'humidité climatique et de l'indice de sévérité de sécheresse de Palmer ont été générées à partir de données maillées de température et de précipitation de la zone boréale canadienne couvrant la période de 1951 à 2010. Les valeurs annuelles des indices de 2011 à 2100 ont été générées à partir des projections du climat à venir dérivées de quatre modèles de circulation générale tirées de trois scénarios démissions de gaz à effet de serre. Les modèles de régression linéaires entre les indices et le temps ont été ajustés pour étudier les tendances à long terme. Les résultats indiquent que plusieurs grandes régions de la forêt boréale canadienne ont connu des périodes de sécheresse importante entre 1951 et 2010. Les projections ont démontré une tendance générale vers des conditions plus sèches au cours du XXIe siècle. Par ailleurs, lanalyse a souligné des périodes de sécheresse plus fréquentes ou encore plus sévères pour l'ensemble des portions occidentales et centrales de la forêt boréale au cours des prochaines décennies. Ces projections des indices sont pertinentes en aménagement forestier parce que la disponibilité de l'humidité du sol est un facteur important de la distribution des arbres, de leur santé et du succès de leur régénération. Les connaissances sur l'importance des changements potentiels à venir au niveau de loccurrence des périodes de sécheresse et de leur intensité aideront les aménagistes forestiers et les décideurs par l'incorporation des éléments liés aux changements climatiques dans leur planification et leurs pratiques d’aménagement forestier.

Mots clés : impacts des changements climatiques, adaptation, planification de laménagement forestier, incertitude, scénario, modèles de circulation générale, gaz à effet de serre, indice d'humidité climatique, indice de sévérité de sécheresse de Palmer, forêt boréale

\section{Introduction}

According to recent estimates, Canada's boreal zone extends over more than $5 \times 10^{6} \mathrm{~km}^{2}$, of which about $3.1 \times 10^{6} \mathrm{~km}^{2}$ are forested (Brandt 2009, Price et al. 2013). Much of the boreal zone is considered vulnerable to the effects of imminent and relatively severe climate change, which will threaten the ecological, social, and economic benefits of boreal forests to Canada and the world (Williamson et al. 2009, Price et al. 2013). This vulnerability has important implications for long- term forest planning aimed at enhancing Canada's ability to achieve the objectives of sustainable forest management (SFM) and for decisions made today that have long-term implications (e.g., regarding reforestation) (Johnston et al. 2010, Edwards and Hirsch 2012). Given that a warmer climate may also lead to a drier forest environment over extensive regions, a method for gauging how moisture deficits may change in extent, frequency, and intensity could be extremely useful in addressing SFM adaptation needs.

\footnotetext{
${ }^{1}$ Northern Forestry Centre, Canadian Forest Service, Natural Resources Canada, 5320 - 122 Street, Edmonton, Alberta T6H 3 S5.

${ }^{\star}$ Corresponding author. E-mail: Yonghe.Wang@NRCan-RNCan.gc.ca

${ }^{2} \mathrm{http}: / / w w w 1 . n c d c . n o a a . g o v / p u b /$ software/palmer/pdi.f, [accessed June 2014]
} 
Climate change is now affecting and will have future impacts on a number of components and values associated with Canada's forest sector. For example, increases in temperature could have either favourable or adverse impacts on various forest types in all regions. Forest productivity, fire occurrence, and the distribution of forest cover are strongly affected by soil conditions and climate variables, including moisture and temperature regimes (e.g., Spurr and Barnes 1980, Smith and Tirpak 1989, Winnett 1998, Nigh 2006, Hogg et al. 2008). It is therefore highly probable that current forest planning and management practices (including reforestation, harvest planning, land-use planning, and forest protection) will need to be modified to ensure the long-term sustainability of forest values and benefits of importance to stakeholders (Johnston et al. 2010, Edwards and Hirsch 2012).

Much of our collective knowledge about how global and regional climates may change in coming decades derives directly or indirectly from simulations performed using coupled general circulation models (GCMs). These complex models represent processes in the atmosphere, ocean, cryosphere, and land surface, using three-dimensional global grids for the atmosphere and oceans and surface parameterization "schemes" to represent exchanges of mass and energy between the atmosphere and terrestrial and cryospheric surfaces. GCMs are used to simulate large-scale responses of the global climate system to increasing greenhouse gas (GHG) concentrations and other factors, such as changes in global land cover (e.g., Randall et al. 2007).

However, at regional and smaller scales, GCM projections are less precise. In the current study results from four wellestablished GCMs, forced by three GHG emissions scenarios, were downscaled to the area of Canada, as described by Price et al. (2011). The four GCMs were the medium-resolution Coupled Global Climate Model version 3.1 (CGCM3.1) developed by the Canadian Centre for Climate Modelling and Analysis (e.g., McFarlane et al. 2005, Scinocca et al. 2008); the Commonwealth Scientific and Industrial Research Organisation (CSIRO) Mk3.5 climate model (CSIRO3.5) (e.g., Gordon et al. 2010); the Japanese medium-resolution Model for Interdisciplinary Research on Climate, version 3.2 (MIROC3.2) (e.g., Nozawa et al. 2007, Watanabe et al. 2008); and the US National Center for Atmospheric Research Community Climate System Model, version 3.0 (NCAR CCSM3.0) (e.g., Gent et al. 2011). The downscaling procedure combined the imprecise projections of change derived from each GCM with high-resolution mapping of observed climate data (e.g., McKenney et al. 2006a), to allow more detailed assessment of localized changes.

Imprecision of climate models (particularly at local scales), combined with the uncertainty in projections of future atmospheric GHG concentrations, means that little confidence can be attached to any single projections of climate generated by any one GCM. Climate change effectively adds to the level of uncertainty facing forest managers in mediumto long-term planning and decision-making. The scenarios approach is therefore proposed as a tool to support planning and decision-making under this increased uncertainty (e.g., Duinker and Greig 2007, Price and Isaac 2012). The future trajectories of GHG emission is highly uncertain, and scenarios provide alternative images of how the major driving forces of human population growth, socio-economic development, and technological change may influence future GCM emissions. This approach permits the assessment of associated uncertainties in climate change.

The consensus of GCM projections indicates that increases in atmospheric GHGs will lead to warmer air temperatures throughout the Canadian boreal zone. Price et al. (2013) estimated that the average warming in the Canadian boreal will almost certainly be at least $2^{\circ} \mathrm{C}$ by 2050 , relative to mean temperatures in 2000. Although it is widely accepted that the cold boreal climate currently limits productivity and the northern distribution of boreal vegetation, climate moisture deficiency is an important climate constraint in drier regions such as the southern edge of the boreal forest and aspen parkland regions of western Canada (Zoltai et al. 1991, Hogg 1994, Hogg and Hurdle 1995, Thompson et al. 1996, Hogg et al. 2008). Soil moisture deficits would be expected to become more severe in these regions (i.e., they would become more widespread, more frequent, and/or more intense), even though annual precipitation is generally projected to increase, because higher mean temperatures will drive increased evapotranspiration (e.g., Zoltai et al. 1991, Hogg and Hurdle 1995). Hogg (1994) found that the distribution of boreal forest and prairie grasslands in western Canada corresponded closely with climate moisture regimes, leading him to suggest that moisture limitations prevent conifer regeneration south of the existing boreal boundary (Hogg and Schwartz 1997). Hogg and Hurdle (1995) found that a projected 11\% increase in precipitation would be insufficient to offset the increase in potential evapotranspiration (PET) resulting from a projected warming of $4^{\circ} \mathrm{C}$ to $5^{\circ} \mathrm{C}$ in mean annual air temperature (consistent with recent projections of temperature increase by 2100 , assuming that GHG emissions continue on their present trajectory). Their analysis suggested that approximately half of the western Canadian boreal forest could be exposed to a drier climate in the future, similar to that of the presentday aspen parkland, where conifers are generally absent and aspen is restricted to patches of stunted trees interspersed with grassland.

Recent severe droughts have been implicated as a major cause of episodic dieback and mortality in the southern Canadian boreal forest (e.g., Michaelian et al. 2011, Peng et al. 2011, Luo and Chen 2013) and in many regions around the globe (Allen et al. 2010). Examining historical spatiotemporal patterns and variations in climate moisture regimes should be useful in analyzing whether changes in these regimes have affected stand dynamics across the managed portion of Canada's boreal zone. Examining projected future changes in climate moisture regimes would then provide valuable insights for estimating future changes in forest productivity and distribution, and hence for adapting forest management practices under a changing climate.

Palmer (1965) defined a drought period as "an interval of time, generally on the order of months or years, during which the actual moisture supply at a given place rather consistently falls short of the climatically expected or climatically appropriate moisture supply." Spatialized indices of drought intensity and duration (e.g., Keyantash and Dracup 2002, Dai 2011) are useful for tracking past trends, identifying "hot spots," and projecting how these may change in response to 
long-term trends in temperature or precipitation. The Palmer Drought Severity Index (PDSI) (e.g., Palmer 1965, Alley 1984), and the Climate Moisture Index (CMI) (e.g., Hogg 1997, Henderson et al. 2002, Hogg et al. 2013) are two widely used drought indices that can be mapped easily using relatively few climate variables. In summary, PDSI can be considered a "relative" measure of moisture conditions as it reports the departure from a local normal condition of soil moisture variability based on the long-term historical distribution. Conversely CMI can be regarded as an "absolute" measure of moisture conditions, in the sense that it reports the absolute difference between precipitation and PET.

The present study investigates how climate change might affect boreal moisture regimes by comparing CMI and PDSI across space and time. Annual values were calculated for the period 1951 to 2010 from climate station data, and projections for 2011 to 2100 were derived from the GCM simulations of future climate. Means and linear trends were computed for each index and were then used to assess the significance of the projections for certain terrestrial ecozones. Past and future projections were compared and their potential implications for boreal forest productivity and distribution assessed.

\section{Data and Methods $\mathrm{CMI}$ and PDSI}

The CMI (Hogg 1997) is a measure of expected moisture regimes based on the difference between annual precipitation and annual PET, where PET is defined as the estimated loss of water vapour from well-established vegetation when soil moisture is not limiting. Here, the Penman-Monteith model (Monteith 1965), as simplified by Hogg (1997), was used to calculate PET. Briefly, CMI can be computed at any geographic location, knowing elevation, monthly total precipitation, and mean daily minimum and maximum temperatures for each month of the year. Saturation vapour pressure (SVP) is estimated using Lowe's (1977) sixth-order polynomial approximation, where SVP is linearly and positively related to the average of the minimum and maximum temperatures. The "simplified Penman-Monteith" method of estimating PET assumes a standard mean canopy conductance of 5 $\mathrm{mm} \cdot \mathrm{s}^{-1}$ (for mean temperature $>10^{\circ} \mathrm{C}$ ), which decreases linearly to zero as mean monthly temperature decreases from $10^{\circ} \mathrm{C}$ to $-5^{\circ} \mathrm{C}$ (Hogg 1997). In this study, we used the "tree water-year CMI," defined as the summation of monthly CMIs from 1 August of the previous year to 31 July of the current year. In a previous study of regional-scale aspen growth responses, Hogg et al. (2005) found this water-year gave the strongest correlations between $\mathrm{CMI}$ and width of tree growth rings. However, CMI results presented here are insensitive to the choice of time period, because this study reports mainly on mean values or trends over periods of 10 years or longer.

The long-term annual mean CMI for sites in Canada's boreal forests is usually positive, indicating generally moist conditions sufficient to maintain the existence of forest cover, although negative values may occur during periods of drought (e.g., Hogg et al. 2008). The isoline where CMI $=0$ over periods of decades or longer indicates a balanced moisture condition (precipitation $\approx \mathrm{PET}$ ), which approximates the southern boundary between forest and grassland in western Canada (Hogg 1997, Hogg and Bernier 2005).
The PDSI (Palmer 1965) differs from CMI in that it is based on a soil water balance model used to estimate whether conditions are wetter or drier than the long-term mean at a given location. PET was estimated using the Thornthwaite and Holzman (1942) equation (as described by Palmer 1965), although it is widely recognized that this formulation can give unrealistic values at high latitudes, because day length (rather than the diurnal radiation integral) is included in the equation. This could therefore cause the PDSI to give different results from other drought indices based on more physically correct PET formulations such as the Penman-Monteith model (e.g., Trenberth et al. 2014).

Available soil moisture storage in the PDSI is represented by dividing the soil profile into two layers and assuming that a certain amount of water can be stored in the surface layer. The lower layer has a location-specific storage capacity, from which moisture cannot be extracted until all available moisture has been removed from the surface layer. Each soil layer is assumed to have a moisture storage capacity. Detailed measurements of soil water-holding capacity do not exist for the Canadian boreal region, so we assumed a combined soil available moisture capacity of $300 \mathrm{~mm}$ for the entire domain. Alley (1984) has pointed out that PDSI computations are often insensitive to the inclusion of available moisture capacity in the top layer. Usually, the PDSI is calculated weekly or monthly; for this study we used monthly values. Positive and negative PDSI values are dimensionless, representing conditions that are relatively wetter and drier, respectively, than the long-term mean. To maintain consistency with the CMI water-year calculations, PDSI was computed using the mean of 12 monthly values of both temperatures and precipitations from 1 August of the previous year to 31 July of the current year.

PDSI was originally calibrated for deep prairie soils of the central US and may not be as well designed for forest soils across Canada. However, many forest types in the Canadian boreal zone, such as aspen forests, have deep soils and rooting depths that translate into relatively high soil water-holding capacity in the rooting zone (Hogg et al. 2013). Although PDSI has become a widely recognized standard for measuring meteorological drought, it has limitations. One of the most common complaints is that PDSI values are not comparable spatially. To address this issue, a self-calibrating PDSI was proposed. Wells et al. (2004) compared the original PDSI and the self-calibrating version, and they found that the results from the two versions are the same in tracking extreme periods of drought or excessive wetness. The standard PDSI appears to meet our need and was adopted for this study.

Both CMI and PDSI are indices that remain independent of vegetation or forest type. As long as precipitation data (as rain or snow water equivalent) are available, the two indices can be calculated with precipitation and temperature as input. Both indices are necessarily simplistic to enable large-scale mapping from basic climatic variables across heterogeneous landscapes. Hogg et al. (2013) used the same simple variables of precipitation and PET to drive a simple model that was remarkable successful in simulating observed changes in soil water content at an old aspen experimental site over a nineyear period in a boreal site in northern Alberta. 


\section{Standardization of the CMI and PDSI}

The Standardized Precipitation Index (SPI; McKee et al. 1993) determines the occurrence of drought conditions using precipitation as its input. The SPI is based on the cumulative probability of a given rainfall event occurring at a specified location. Historical precipitation amounts are first fitted to a Gamma or Pearson type III distribution. Then, the fitted cumulative probability functions are mapped to the standard normal distribution, a value usually referred to as the $Z$ value, with a mean of 0 and variance of 1 . Based on $Z$ values, one can determine whether precipitation at a given location in a given time is greater or less than the long-term normal value. In the current analysis, however, we did not calculate SPI values because precipitation amount is not an ideal indicator of drought stress on forests (Hogg 1994). Instead, the SPI procedure was used to convert monthly CMI and PDSI data to their corresponding $Z$ values. The purpose of this exercise was twofold. First, CMI is an absolute measure of the moisture condition. Therefore, once it has been standardized, the CMI $Z$ value becomes a relative measure that can be compared directly to the PDSI. Second, although the PDSI is a relative indicator, its variance is not necessarily equal to 1 (as would be expected from a measure with normal distribution). Thus, for the current study, the PDSI values were also standardized to generate $Z$ values with similar distribution to that of the CMI $Z$ values (i.e., mean of 0 and variance of 1 ).

\section{Historical monthly climate data, 1951 to 2010}

Historical climate station records of monthly mean daily maximum and minimum temperatures and monthly total precipitation were extracted from data covering Canada for the period 1901 to 2010, interpolated to a $10 \times 10 \mathrm{~km}$ grid covering the area of Canada on the Lambert Conformal Conic map projection (e.g., McKenney et al. 2006a, Price et al. 2011). The spatial coverage of historical climate data for boreal Canada was relatively poor during the first half of the $20^{\text {th }}$ century (Price et al. 2013); therefore, only data for 1951 to 2010 were used for the present analysis. The grid consists of 480 rows and 570 columns reprojected using ARC GIS from a $0.083^{\circ}$ resolution geographic grid covering Canada and the continental USA, generated in turn using ANUSPLIN software (e.g., Hutchinson 1998, 2006). ANUSPLIN employs thin-plate smoothing splines (e.g., Wahba 1985) and is capable of developing elevation-dependent, spatially continuous climate surfaces from noisy observational data (e.g., McKenney et al. 2011).

The approach has been subjected to rigorous testing to examine the predictive accuracy of the historical surfaces (e.g., Price et al. 2000; Simpson et al. 2005; McKenney et al. 2006a,b, 2013). It has been established that the magnitude of errors at "withheld" climate stations in areas where such stations are sparsely distributed is generally about $\pm 1.0^{\circ} \mathrm{C}$ to $1.5^{\circ} \mathrm{C}$ for monthly mean daily minimum and maximum temperatures and $\pm 20 \%$ to $40 \%$ for precipitation. Predictive accuracy of the surfaces varies over time, with a modest improvement over time through the $20^{\text {th }}$ century, coincident with expansion of the climate station network (McKenney et al. 2006a,b). ). Considerable spatial variation exists in predictive accuracy across the continent with mountainous and coastal regions exhibiting the largest errors in both temperature and precipitation.
Simulated future monthly climate data, 2011 to 2100

Twelve GCM scenarios of future climate resulting from the B1, A1B, and A2 GHG emissions scenarios of the Intergovernmental Panel on Climate Change (IPCC) Special Report on Emissions Scenarios (Nakićenović et al. 2000) were used in this study (for details, see Price et al. 2011). Simulation results for each GHG scenario were obtained for the four GCMs listed previously. The main criteria for selecting these particular GCMs were that the necessary climate variables were available and that they had well-established reputations. Global data sets for single realizations of each GCM forced by each emission scenario were downloaded from the Coupled Model Intercomparison Project Phase 3 (CMIP3) archive established for the Program of Climate Model Diagnosis and Interpretation and maintained by the World Climate Research Program at Lawrence Livermore National Laboratory (California). Future projected changes in monthly mean daily minimum and maximum temperature and precipitation were interpolated as two-dimensional (latitude and longitude) models using ANUSPLIN, with GCM grid nodes treated as if they were climate stations reporting changes relative to the means of the GCM-simulated monthly data for 1961 to 1990 . Following Price et al. (2011), the change data were computed as differences for temperature and as ratios for precipitation. The ANUSPLIN models were then used to generate grids on a geographic projection covering North America at resolution of $0.0833^{\circ}$ (300 arc seconds). As with the historical climate data, the grids of GCM-simulated changes were then re-projected using Arc-GIS to the Lambert Conformal Conic projection at nominal $10-\mathrm{km}$ grid resolution. As a final step, the grids of monthly projected changes in mean daily temperature and precipitation were converted to absolute values by combining them with the gridded historical monthly normals data for the period 1961 to 1990 , as follows: interpolated temperature differences were added to the interpolated historical normals, and precipitation ratios were multiplied by the normals.

\section{Creation of annual tree water-year CMI, PDSI, and their $Z$ value grids}

Equations provided by Hogg et al. (2013) for the simplified Penman-Monteith method were coded in Fortran 95 to calculate CMI. The Fortran 77 programs used to calculate PDSI were obtained from the National Climate Data Center of the US National Oceanic and Atmospheric Administration ${ }^{2}$. To calculate PDSI, we first computed average values of PET, together with potential recharge, potential loss, and potential runoff for 12 months. From these four potential values, the time series of temperature and precipitation, and the initialized values of PDSI, the PDSI series were computed iteratively month by month. The monthly grids of the CMI and PDSI were then constructed and used as input to generate yearly time series of tree water-year grids of the CMI and PDSI and the corresponding grids of their respective $Z$ values.

\section{Statistics for annual tree water-year CMI and PDSI grids}

Linear trends were calculated by simple regression (e.g., Dai et al. 2004), where a statistically significant negative value of the regression slope parameter $(b)$ was interpreted as implying a trend of decreasing moisture availability (i.e., increasing drought). However, extreme drought events with shorter 


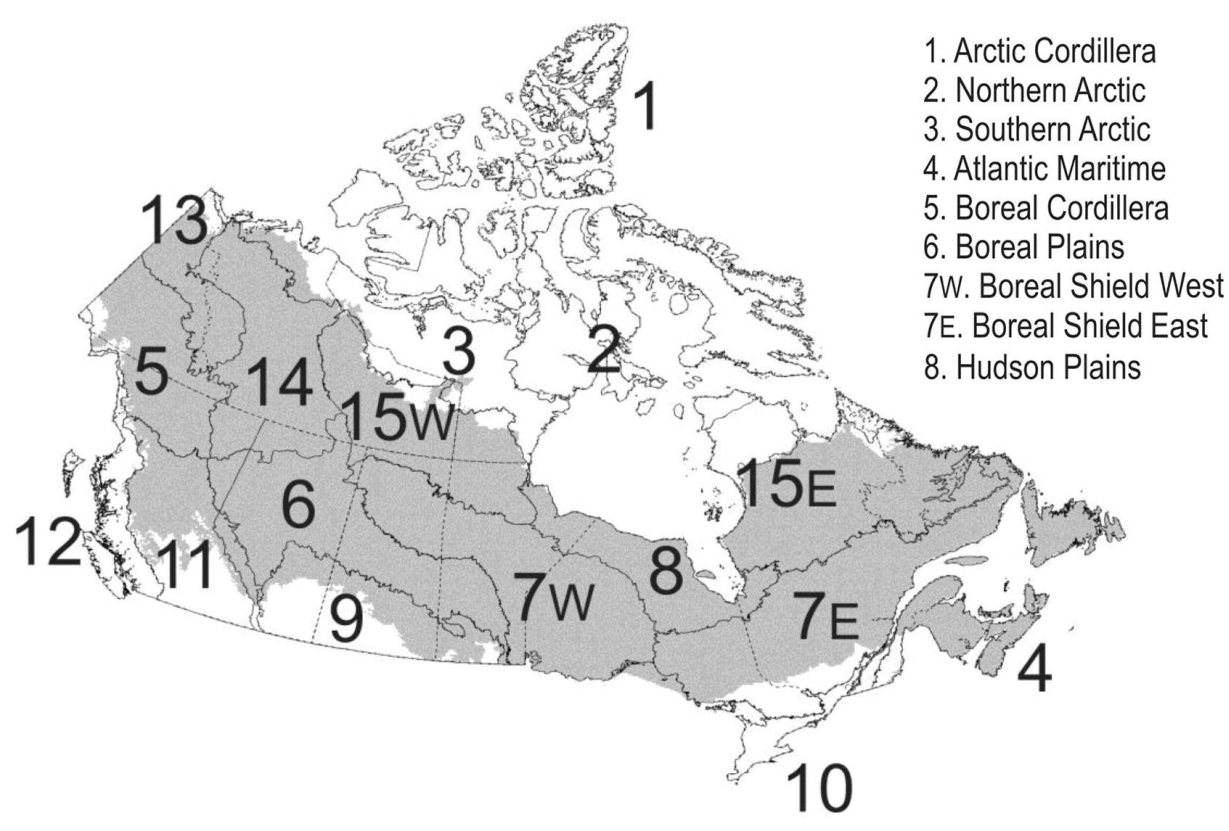

9. Aspen Parkland of Prairie

10. Mixedwood Plains

11. Montane Cordillera

12. Pacific Maritime

13. Taiga Cordillera

14. Taiga Plains

15W. Taiga Shield West

15E. Taiga Shield East

Fig. 1. The Canadian boreal forest zone (grey areas) and 15 Canadian terrestrial ecozones (bounded by solid lines); dashed lines are provincial and territorial boundaries.

periodicities may also exist in the projected long-term CMI or PDSI series. Shorter-term extreme drought events have been observed to result in massive aspen dieback such as happened in western Canada (Michaelian et al. 2011) and other vegetation diebacks related to drought around the world (Allen et al. 2010). Examining periodic properties of the projected CMI and PDSI series is beyond the scope of this study.

Grids of decadal mean CMI and PDSI, and their corresponding $Z$ values, were calculated cell by cell for each of the six decades, using annual data for 1951 to 2010, to assess historical decadal spatiotemporal trends in these indices across the Canadian boreal zone. The annual data were also used to derive values of the linear regression parameter $b$ and their significance levels for each grid cell over the entire 1951 to 2010 period. For the projected future trend in moisture conditions, the linear regression parameter $b$ was estimated for each grid cell for the period 2011 to 2100 for each of the 12 projections of future climate, for terrestrial ecozones located entirely or predominantly in the managed region of the boreal forest (namely, the Atlantic Maritime, the portion of Aspen Parkland in Prairie, Boreal Plains, Montane Cordillera, Boreal Shield East, and Boreal Shield West; see Fig. 1). Time series of annual CMI and PDSI, spatially averaged for the six ecozones, were then plotted to show projected temporal variations in moisture regimes for the different GCM scenarios. Finally, linear regression was conducted on these time series to reveal possible temporal patterns of moisture dynamics.

\section{Results}

Fig. 2 presents maps of six decadal means (for the period 1951 to 2010) for CMI and PDSI, computed from the historical time series of observed climate data for all grid cells. Fig. 3 presents the same data, expressed in terms of the $\mathrm{CMI} Z$ value and the PDSI $Z$ value. The spatial distributions of positive and negative CMI values varied considerably from decade to decade (Fig. 3), indicating considerable geographic variation in the decadally averaged moisture balance. Within this temporal variability, however, moist conditions (CMI >20) occurred consistently across most of the eastern and central areas of the boreal zone, as well as in higher-elevation areas of western Canada. Drier conditions $(\mathrm{CMI}<0)$ occurred consistently in the Aspen Parkland and adjacent areas of the western boreal forest and in several outliers in low-elevation areas of northwestern Canada, although the intensity of these drier conditions varied by decade. The PDSI provides a clearer measure of decadal variation in moisture because it shows the departure from locally normal moisture conditions (estimated from their historical distribution). This has the effect of removing the persistent regional variation that is apparent in the maps showing decadal mean values of CMI. In comparison, the spatial distribution of the CMI $Z$ values indicates whether average conditions in each given decade were drier or wetter than the long-term average. In this respect, the CMI $Z$ value is more directly comparable to the PDSI.

Overall, all three of the relative moisture indices (CMI $Z$ values, PDSI, and PDSI $Z$ values) showed similar decadal patterns. The decades of 1951 to 1960 and 2001 to 2010 were notably drier than the long-term average (1951 to 2010). In the 2001 to 2010 decade, all of these indices indicated areas of exceptional dryness in each of the six boreal ecozones (Fig. 2 and Fig. 3). The similarities of trends in PDSI to trends in CMI $Z$ values and PDSI $Z$ values indicate that the PDSI is an acceptable proxy for the standardized indices. Hence, subsequent analyses focused on assessing the statistical significance of the long-term trends in CMI and PDSI, and no further discussion of CMI $Z$ values and PDSI $Z$ values is warranted. 


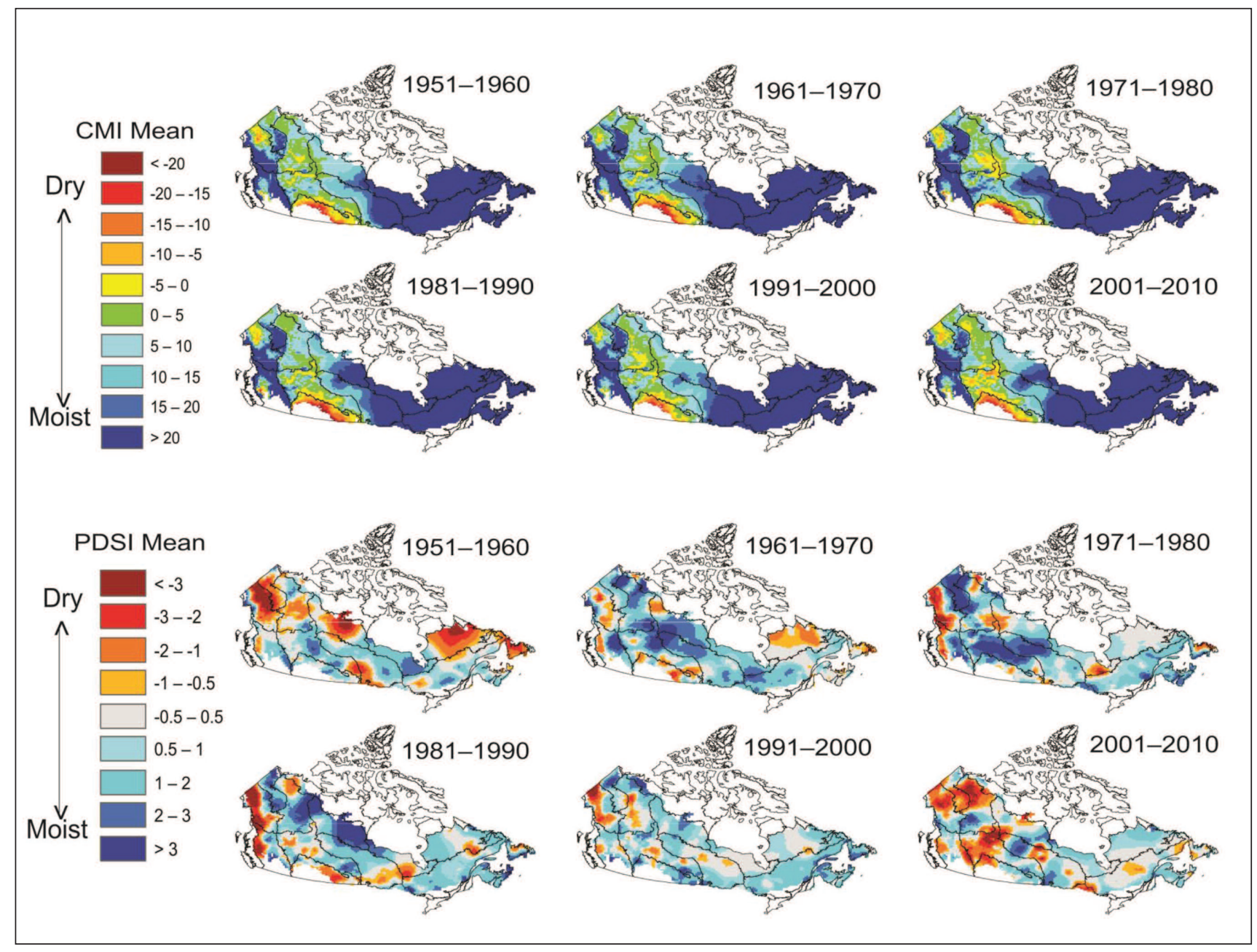

Fig. 2. Decadal grid-cell means of Climate Moisture Index (CMI) and Palmer Drought Severity Index (PDSI) for the six decades over the period 1951 to 2010.

The maps in Fig. 4 show the change in moisture conditions during the historical period 1951 to 2010, based on the linear regression parameter $b$ and its statistical significance for the two drought indicators (CMI and PDSI). The reported values of $b$ indicate the average linear trend per year, where negative values denote a trend toward drier conditions. The annual trend can be easily converted to the linear trend per decade simply by multiplying by 10 . The two drought indices generated similar results, although the CMI was more conservative in representing the forested regions where significant changes in moisture conditions have occurred over the 60-year historical period. The analyses based on both CMI and PDSI showed large areas of forest with significant drying, especially in western and central regions of Canada. In contrast, much of northeastern Canada showed a significant trend toward wetter conditions. Notably, both indices showed a high degree of sub-regional spatial variability between areas with significant drying and those with significant moistening.

The maps in Fig. 5 show spatial variations in the projected future rates of change (i.e., linear regression parameter $b$ ) in CMI and PDSI, respectively, for the period 2011-2100 for each of the 12 projections of future climate. Overall, the spatial patterns were similar when projected linear trends of the CMI
(Fig. 5, upper panel) were compared with those of the PDSI (Fig. 5, lower panel) for each model and GHG forcing scenario. However, there were some notable differences. For example, under the CGCM3.1 projections forced by the A1B and A2 emissions scenarios, the region west of Hudson Bay showed significant future drying (strongly negative linear regression parameter $b$ ) with the PDSI, whereas the CMI showed little change (Fig. 5: compare CMI maps of CGCM3.1 A1B and CGCM3.1 A2 with PDSI maps of CGCM3.1 A1B and CGCM3.1 A2). Consistent with other comparisons of GCM results, MIROC3.2 predicted stronger drying trends than other GCMs across most of the boreal zone (Fig. 5, upper panel: maps of MIROC3.2 B1, A1B, and B2). The range of variation in these drying trends among GHG scenarios was smaller for the CGCM3.1 model than for the other GCMs (maps of CGCM3.1 B1, A1B, and A2). Generally, however, the northeastern areas of Canada were projected to become wetter or remain near their current mean moisture balances in the 21st century. In contrast, most of the GCM scenarios indicated increasing drought across much of west-central Canada, including the Boreal Plains, Boreal Shield West, and Aspen Parkland. Again, the CGCM3.1 projection was a notable exception, in that it indicated generally wetter conditions in 


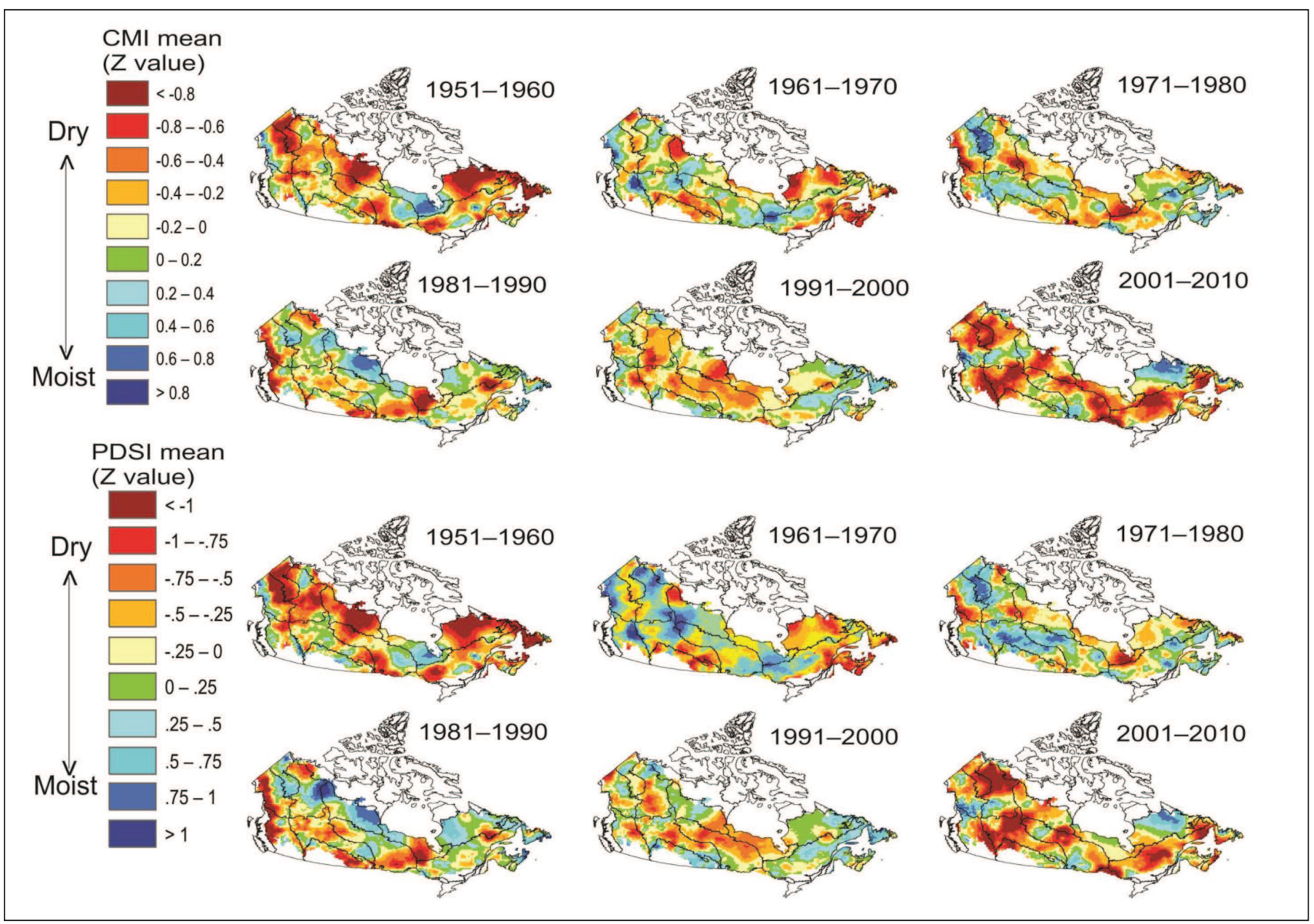

Fig. 3. Decadal grid-cell means of $Z$ values for Climate Moisture Index (CMI) and Palmer Drought Severity Index (PDSI) for the six decades over the period 1951 to 2010.
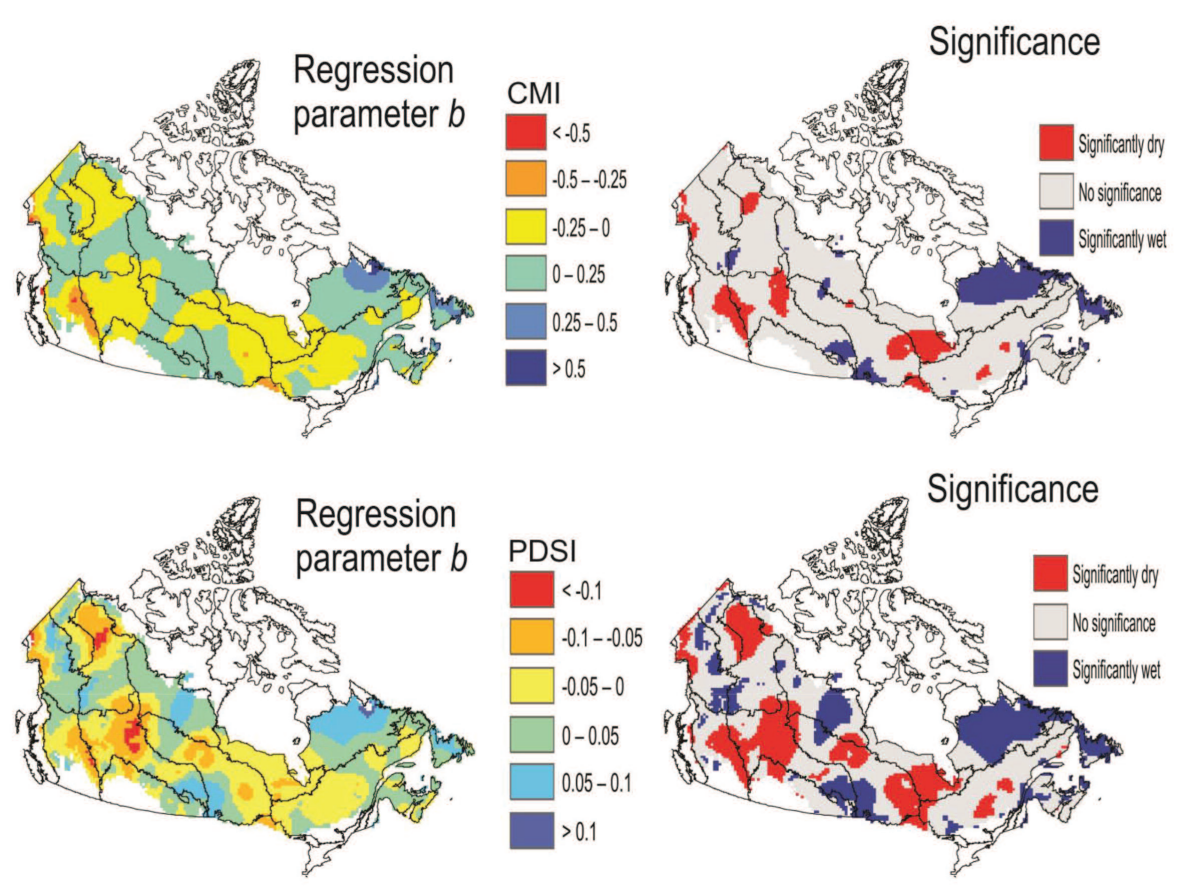

Fig. 4. Trends in moisture regimes over the period 1951 to 2010 based on values of the linear regression parameter b, and its statistical significance for the Climate Moisture Index (CMI) and the Palmer Drought Severity Index (PDSI). Negative values of b denote a drying trend. 

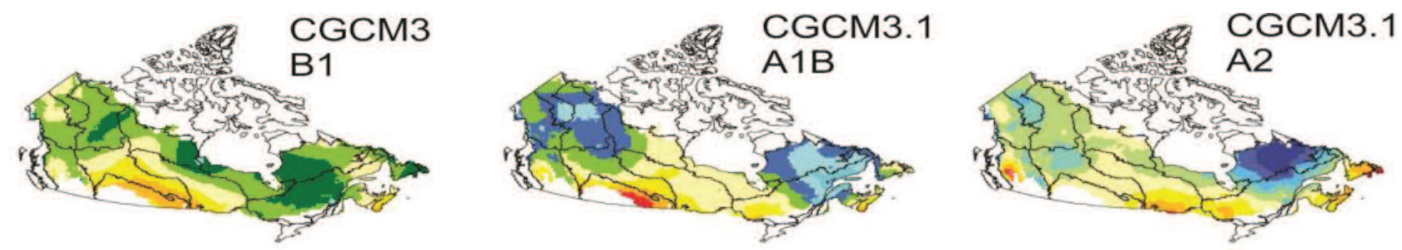

09 CSIRO3.5

B1
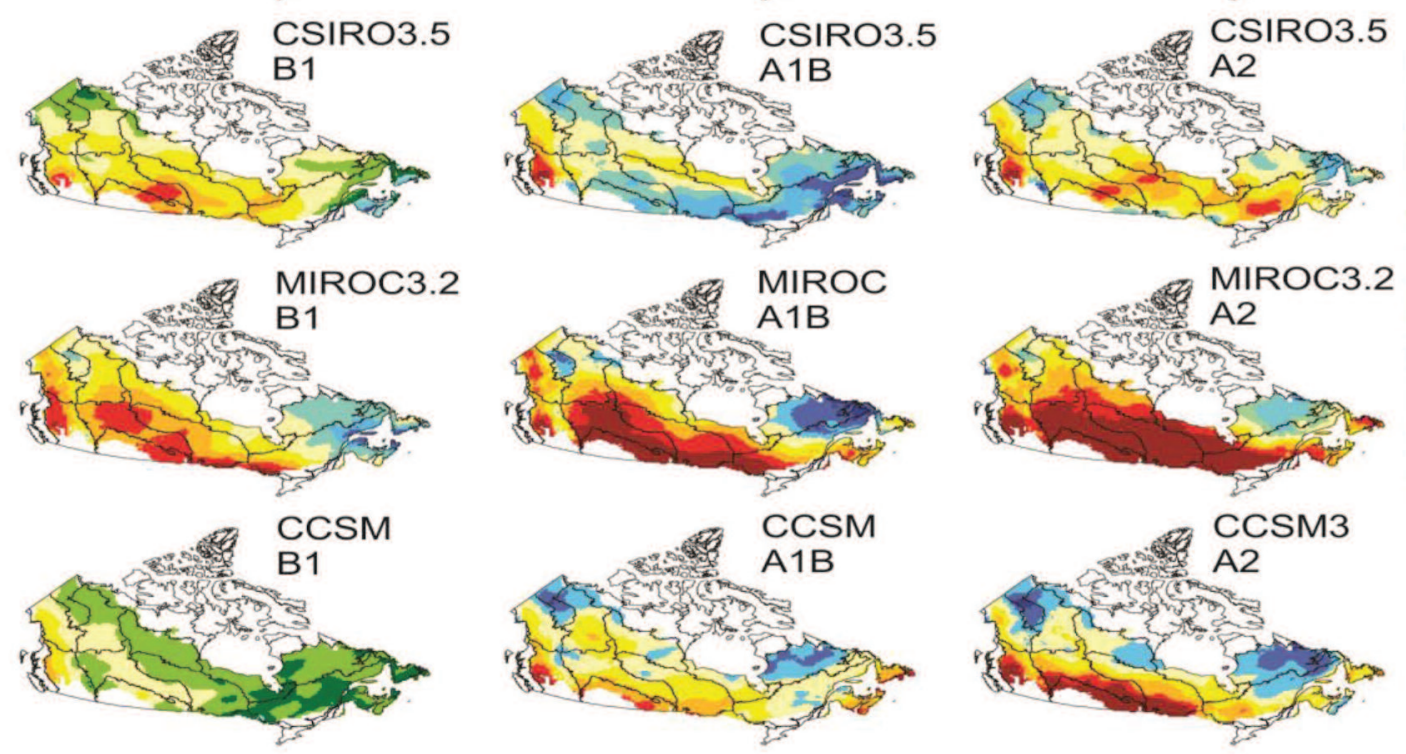

$\mathrm{CMI}$

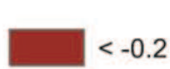

$-0.2--0.15$

$-0.15--0.1$

$-0.1--0.05$

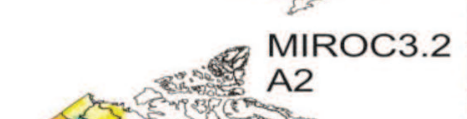

$-0.05-0$
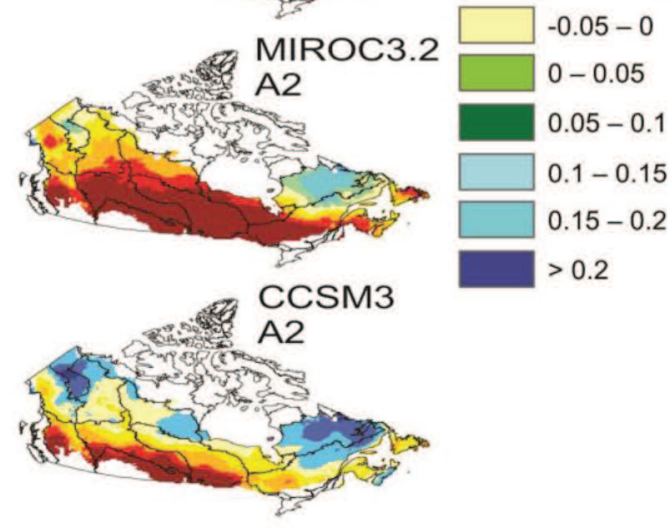

0.2
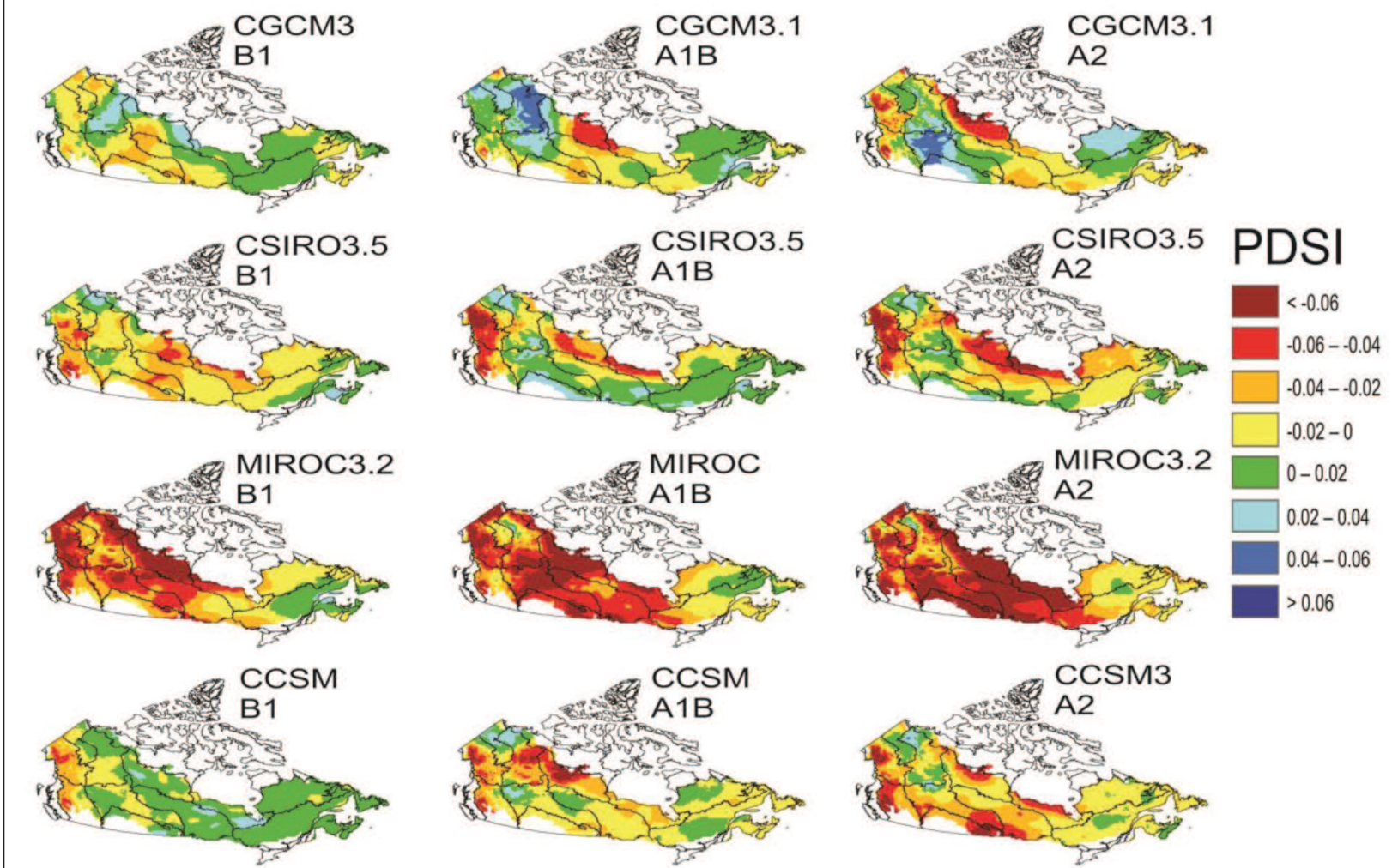

Fig. 5. Estimated future trends in moisture regimes over the period 2011-2100 based on values of the linear regression parameter $b$ for the Climate Moisture Index (CMI) and the Palmer Drought Severity Index (PDSI). 

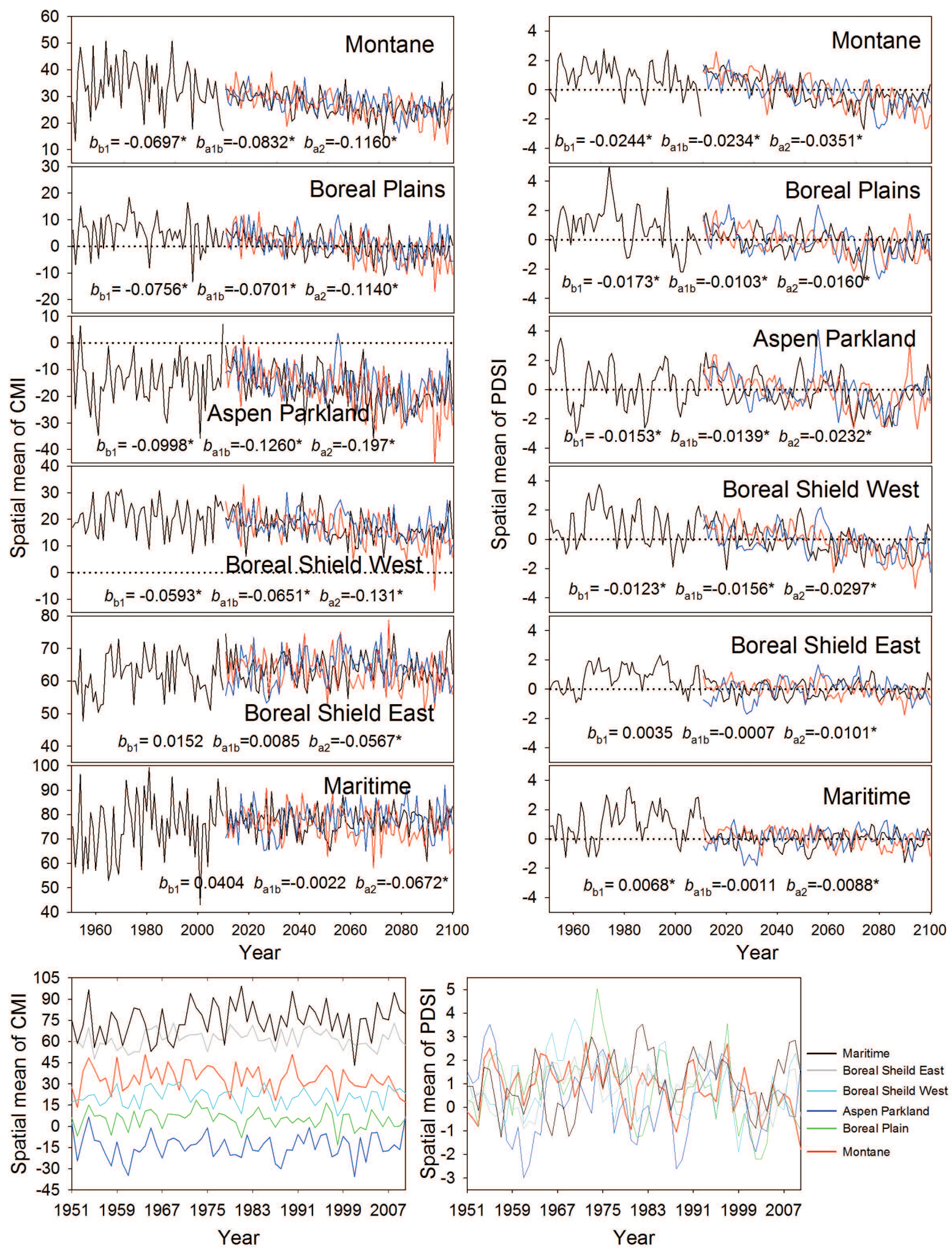

Fig. 6. Time-series plots of annual Climate Moisture Index (CMI) and Palmer Drought Severity Index (PDSI), spatially averaged for the Montane Cordillera, Boreal Plains, Aspen Parkland, Boreal Shield West, Boreal Shield East, and Atlantic Maritime terrestrial ecozones. Each line is the mean of four general circulation models (one projection per model), each forced by the same greenhouse gas (GHG) emission scenario (where blue, black, and red represent GHG emissions scenarios B1, A1B, and A2, respectively). Data for the period 1951 to 2010 are spatial averages of CMI and PDSI calculated from historical climate observations. For the CMI plots, the position of the zero line in the vertical scale differs among ecozones. Linear regression parameter b was included for each GHG emission scenario; subscripts of b represent the scenarios, and an asterisk indicates statistical significance. 
the western portion of the Boreal Plains ecozone, which is likely due to differences in the details of the structure and parameterization of CGCM3.1 compared to other GCMs.

Fig. 6 presents graphs of spatially averaged mean CMI (left column) and PDSI (right column) over the period 1951-2010, for each of the six boreal ecozones shown in Fig. 1. Two plots at the bottom of Fig. 6 are the general historical trend trajectories for the six ecozones from 1951 to 2011. For the plots showing future projections, we first computed the 12 time series of annual spatially averaged means for all GCM $\times$ scenario combinations. Then, we averaged the results for all four GCMs forced by each GHG emissions scenario to produce time series for each of the three GHG scenarios. Linear regression was applied to these three time series, with time as the independent variable; the values of parameter $b$ are presented to show the significance of linear trends. For the east- ern ecozones (Atlantic Maritime and Boreal Shield East), the CMI showed no obvious moisture trends with the A1B and B1 emission scenarios, but a significant drying trend appeared with the A2. Similar results occurred for the PDSI, although a trend toward wetter conditions appeared for the B1 scenario in the Atlantic Maritime ecozone. For the other four ecozones, significant decreasing trends could be discerned for both the CMI and the PDSI, judging from the negative $b$ values for all three scenarios; indicating that these ecozones are more likely to become drier in the future. The information shown in the plots is complementary to the spatial patterns in Fig. 5, in that they reveal the temporal trends of projected future changes in moisture conditions.

Table 1 shows the projected future (2011 to 2100) change in moisture regime for the six boreal ecozones. The $b$ values from the MIROC3.2 were almost always negative, the only

Table 1. Estimated b values for the CMI and PDSI spatial mean time series over the period 2011 to 2100 , based on 12 GCM-scenario combinations for six Canadian ecozones (bold indicates statistical significance).

\begin{tabular}{|c|c|c|c|c|c|c|}
\hline \multirow[b]{2}{*}{ Ecozone } & \multirow[b]{2}{*}{ Index } & \multirow[b]{2}{*}{ Scenario } & \multicolumn{4}{|c|}{ GCM model } \\
\hline & & & CGCM3.1 & CSIRO3.5 & MIROC3.2 & CCSM3.0 \\
\hline \multirow[t]{6}{*}{ Montane Cordillera } & \multirow[t]{3}{*}{ CMI } & $\mathrm{B} 1$ & -0.0006 & -0.0902 & -0.1346 & -0.0535 \\
\hline & & $\mathrm{A} 1 \mathrm{~B}$ & 0.0084 & -0.1163 & -0.1203 & -0.1044 \\
\hline & & $\mathrm{A} 2$ & -0.0087 & -0.0932 & -0.1914 & -0.1715 \\
\hline & \multirow{3}{*}{ PDSI } & B1 & -0.0078 & -0.0316 & -0.0404 & -0.0176 \\
\hline & & $\mathrm{A} 1 \mathrm{~B}$ & -0.0051 & -0.0320 & -0.0317 & -0.0248 \\
\hline & & $\mathrm{A} 2$ & -0.0137 & -0.0315 & -0.0504 & -0.0446 \\
\hline \multirow[t]{6}{*}{ Boreal Plains } & \multirow[t]{3}{*}{ CMI } & $\mathrm{B} 1$ & -0.0526 & -0.0868 & -0.1515 & -0.0116 \\
\hline & & A1B & -0.0093 & 0.0079 & -0.2108 & -0.0682 \\
\hline & & $\mathrm{A} 2$ & 0.0100 & -0.0759 & -0.2553 & -0.1357 \\
\hline & \multirow[t]{3}{*}{ PDSI } & $\mathrm{B} 1$ & -0.0119 & -0.0140 & -0.0444 & 0.0013 \\
\hline & & A1B & 0.0086 & 0.0118 & -0.0590 & -0.0027 \\
\hline & & $\mathrm{A} 2$ & 0.0282 & -0.0034 & -0.0628 & -0.0259 \\
\hline \multirow[t]{6}{*}{ Aspen Parkland } & \multirow[t]{3}{*}{ CMI } & B1 & -0.1049 & -0.1228 & -0.1509 & -0.0205 \\
\hline & & $\mathrm{A} 1 \mathrm{~B}$ & -0.1253 & 0.0516 & -0.2974 & -0.1339 \\
\hline & & $\mathrm{A} 2$ & -0.0437 & -0.0740 & -0.3939 & -0.2755 \\
\hline & \multirow[t]{3}{*}{ PDSI } & B1 & -0.0173 & -0.0212 & -0.0288 & 0.0061 \\
\hline & & $\mathrm{A} 1 \mathrm{~B}$ & -0.0151 & 0.0296 & -0.0573 & -0.0126 \\
\hline & & $\mathrm{A} 2$ & 0.0229 & 0.0106 & -0.0821 & -0.0441 \\
\hline \multirow[t]{6}{*}{ Boreal Shield West } & \multirow[t]{3}{*}{ CMI } & $\mathrm{B} 1$ & -0.0208 & -0.0907 & -0.1275 & 0.0236 \\
\hline & & $\mathrm{A} 1 \mathrm{~B}$ & -0.0329 & 0.0318 & -0.1849 & -0.0743 \\
\hline & & $\mathrm{A} 2$ & -0.0437 & -0.0860 & -0.2837 & -0.1111 \\
\hline & \multirow[t]{3}{*}{ PDSI } & $\mathrm{B} 1$ & -0.0067 & -0.0182 & -0.0361 & 0.0118 \\
\hline & & $\mathrm{A} 1 \mathrm{~B}$ & -0.0087 & 0.0059 & -0.050 & -0.0097 \\
\hline & & $\mathrm{A} 2$ & -0.0113 & -0.0169 & -0.0664 & -0.0241 \\
\hline \multirow[t]{6}{*}{ Boreal Shield East } & \multirow[t]{3}{*}{ CMI } & $\mathrm{B} 1$ & 0.0430 & -0.0181 & -0.0186 & 0.0546 \\
\hline & & $\mathrm{A} 1 \mathrm{~B}$ & 0.0409 & 0.1022 & -0.07485 & -0.0342 \\
\hline & & $\mathrm{A} 2$ & 0.0138 & -0.0664 & -0.1523 & -0.0221 \\
\hline & \multirow[t]{3}{*}{ PDSI } & $\mathrm{B} 1$ & 0.0080 & -0.0014 & -0.0020 & 0.0094 \\
\hline & & $\mathrm{A} 1 \mathrm{~B}$ & 0.0028 & 0.0117 & -0.0127 & -0.0044 \\
\hline & & $\mathrm{A} 2$ & -0.0040 & -0.0064 & -0.0248 & -0.0054 \\
\hline \multirow[t]{6}{*}{ Atlantic Maritime } & \multirow[t]{3}{*}{ CMI } & $\mathrm{B} 1$ & -0.0246 & 0.1054 & 0.0768 & 0.0430 \\
\hline & & A1B & 0.0456 & 0.1293 & -0.1079 & -0.0746 \\
\hline & & $\mathrm{A} 2$ & -0.0487 & -0.0462 & -0.1468 & -0.0269 \\
\hline & \multirow[t]{3}{*}{ PDSI } & $\mathrm{B} 1$ & -0.0051 & 0.0172 & 0.0082 & 0.0070 \\
\hline & & $\mathrm{A} 1 \mathrm{~B}$ & 0.0022 & 0.0154 & -0.0135 & -0.0082 \\
\hline & & $\mathrm{A} 2$ & -0.0140 & -0.0002 & -0.0189 & -0.0022 \\
\hline
\end{tabular}


exceptions being for the B1 scenario in the Boreal Shield East and Atlantic Maritime ecozones. Overall, the $b$ values obtained from all MIROC3.2 projections suggest much drier conditions according to this GCM in future decades across nearly the entire Canadian boreal zone. Conversely, the CGCM3.1 model generally predicted the least warming of the four GCMS, and the $b$ values indicated few significant trends in moisture regimes in the future. The remaining two models (CSIRO3.5 and NCAR CCSM3) generated projections that varied considerably according to region and GHG scenario, but there was a consistent tendency toward projected future drying in the more southerly forested regions of western and central Canada. The various combinations of GCMs and emissions scenarios suggested that the Montane Cordillera, Boreal Plains, Boreal Shield West, and Aspen Parkland ecozones are likely to become drier over the period 2011-2100. In contrast, projections for the boreal ecozones of eastern Canada (Boreal Shield East and Maritime) indicate relatively little change in future moisture conditions. Correlation coefficients $(\rho)$ were calculated between the projected overall trends in moisture based on the CMI and the PDSI for all six ecozones under all GCM scenarios. The values of $\rho$ ranged between 0.314 and 0.830 , but all were statistically significant, which confirmed our observation that CMI and PDSI are of similar value in assessing projected and historical changes in moisture conditions.

\section{Discussion and Conclusions}

Consistent with earlier studies (e.g., IPCC 2007, Price et al. 2011), all four GCMs used in this study projected warming trends across the Canadian boreal zone during the 21st century, with the most extreme GHG emissions scenario (A2) creating the greatest warming and the B1 scenario the least. The four GCMs were also consistent in projecting general increases in mean annual precipitation across the Canadian boreal region, although there was much greater spatial variation (and hence greater uncertainty) among scenarios with regard to how precipitation regimes are likely to change than was the case for future changes in temperature regimes. When the projected changes in temperature and precipitation were combined into indices of drought stress, however, the results from the 12 different projections strongly suggested an overall future trend toward drier conditions throughout the boreal ecozones of western Canada. Clearly, the A2 scenario produced the greatest increases in drought and the B1 scenario the least. Based on historical records extending back to the 18th century (e.g., Sauchyn 2005) and the spatial variability of precipitation trends, the projected drying is likely to manifest mainly as increasing frequency and/or severity of seasonal and multiyear drought events.

For the current study, we used two drought indices (CMI and PDSI) that have distinct methods of calculation. Overall, these two indices were highly correlated in our analyses of changes in moisture conditions and in terms of the spatial variation of these changes across the Canadian boreal zone, both for the recent historical period and for all GCM projections to 2100 .

Historically, several regions have experienced significant drying, according to the trends in CMI and PDSI calculated for the period 1951-2010. These regions include western portions of the boreal cordillera (Yukon and British Columbia), the northern part of the taiga plains and adjacent portions of the taiga cordillera (Northwest Territories), the western part of the montane cordillera and adjacent boreal plains (British Columbia and Alberta), the central portion of the boreal plains (Alberta and Saskatchewan), and parts of the boreal shield and Hudson plains (Manitoba, Ontario, and Quebec). The CMI (and to a lesser extent, the PDSI) shown for the Aspen Parkland (Fig. 6) captured the severe drought of 2000-2002 that led to massive aspen mortality in that zone (Michaelian et al. 2011). Both indices also showed the severe 1961 drought that resulted in up to $100 \%$ mortality in aspen groves in the Aspen Parkland of southern Saskatchewan and Manitoba (Zoltai et al. 1991). Interestingly, however, there were also localized areas with significant trends toward wetter conditions over the historical 60-year period, even in the west. The spatial distribution of areas with significant drying and significant moistening was highly variable (Fig. 4), which reflects the highly stochastic variation in moisture conditions and illustrates the difficulty of generating reliable forecasts of future changes in moisture at fine spatial scales or at specific locations.

For the $21^{\text {st }}$ century in Canada, all GCMs discussed in the IPCC's Fourth Assessment Report substantially agreed in projecting significant warming, generally accompanied by increasing amounts of precipitation (IPCC 2007, 2013). However, despite this general agreement, the present study found that the CGCM3.1 model projected the smallest increases in frequency and/or intensity of future drought and the MIROC3.2 model generally projected the largest increases, with results from the CSIRO3.5 and NCAR CCSM3 models falling between these extremes. Also within these general trends, there were some strong regional differences in terms of future changes in moisture regimes as projected by the four GCMs. For example, the northwestern Boreal Plains ecozone was projected to become much drier according to the MIROC3.2 model but somewhat wetter according to the CGCM3.1 model, particularly when forced by the most extreme GHG emissions scenario (A2). These apparently conflicting results can be attributed to differences in the details of the structure and parameterization of the GCMs. Nevertheless, there was considerable consistency in the projections, and several inferences can be drawn.

Based on this and previous studies (e.g., Price et al. 2011), our findings can be summarized as follows: It is very likely that average precipitation in central and northern Canada will increase and that few regions of Canada (if any) will experience significant decreases in precipitation. However, increases in precipitation will not necessarily lead to wetter conditions, because of temperature-induced increases in forest water use (i.e., increased evapotranspiration). The spatial variability of change in future precipitation across the country will be greater than the spatial variability of change in mean future temperature, and extreme drought events are likely to become more frequent (relative to similar events that have occurred during the period covered by our analysis of past climate, 1951 to 2012 ).

On the basis of our analyses of the CMI and the PDSI, we conclude that the combined changes in precipitation and temperature will lead to generally drier conditions in many regions of western Canada, although some regions in the east may become marginally wetter. Regions with low to moderate precipitation, including most of the managed boreal forest in western and central Canada, are more likely to be exposed 
to significant increases in the occurrence of drought (i.e., CMI and PDSI will decrease significantly or will become significantly more negative). In contrast, regions that are currently exposed to high annual precipitation will likely see relatively little change in the occurrence of drought. In general, multiyear drought events will likely become more frequent and/or intense in regions that are already prone to drought.

\section{Potential Implications for Forest Management}

Spittlehouse (2005) noted that forest managers can no longer assume that future climate conditions will be similar to the relatively stable climate conditions observed in recent history. This realization has fundamental implications for forest management planning and practices. In particular, forest managers will need to recognize that climate conditions are likely to change within the lifespan of forests that are being established today, and they will need to consider developing forest management practices appropriate for this new reality.

Forest managers are increasingly called upon to consider climate change and climate variation in all aspects of SFM practices and policies (CCFM 2008, Edwards and Hirsch 2012). However, consideration of the effects of future changes depends on the availability of information and knowledge in a form suited to planning and decision-making. Forest managers must be willing to make decisions with the knowledge that the climate will change, but lacking certainty about the timing and locations of these changes. The scenarios presented in this paper illustrate one approach for incorporating climate change and uncertainty into forest management decision-making and planning at national to regional scales. Scenarios analysis allows plausible alternative futures to be envisioned for the purpose of developing more robust management strategies that can respond to some of this uncertainty.

It should be clear that mapping the range of potential CMI and PDSI (or any other drought index) at 10-km spatial resolution cannot provide the basis for stand-level forest management prescriptions. However, exploring the range of potential future drought indices at regional scales, as presented in the scenarios analysis in this paper, can help forest managers to identify stands or management units where increases in drought frequency and intensity are likely to have adverse impacts, as well as those where drier conditions may be beneficial. In hilly and mountainous regions of western Canada, moisture conditions are strongly affected by local topography, including elevation, slope, and aspect (e.g., Hogg 1994), as well as by soil conditions (e.g., water-holding capacity within the tree rooting zone). Forests growing on poor soils at low elevation are generally much more vulnerable to drought, especially on south- or west-facing slopes. Even within relatively flat areas of boreal forest in western Canada, it is important to recognize that local topographic variation leads to a mosaic of forest types across local moisture gradients, from well-drained uplands to poorly drained lowlands. Under the projected drying trend in this region, it may be reasonable to expect that well-drained sites will experience greater moisture stress, while the poorly drained sites may become more mesic and therefore able to support higher forest productivity. Hence, it may be reasonable to limit management of the impacts of drought stress to the most vulnerable sites, based on the range of CMI projections, while sites that are poorly drained or located at high elevations should be treated alto- gether differently, to capitalize on the potential benefits of warmer and drier conditions.

In general, if forest managers maintain an awareness of projected long-term trends in CMI or PDSI and of the uncertainty (and inherent variability) that surrounds these projections, they will be better able to account for potential changes in the frequency and intensity of drought caused by climate change. This should allow them to be better able to develop forest management practices that are more robust to a range of possible changes in future moisture conditions for inclusion in long-term forest management plans. For example, observed and projected trends in CMI and PDSI indices can be used as "early warning" indicators of potential future impacts such as changes in tree mortality due to drought (Hogg and Bernier 2005, Michaelian et al. 2011), changes in forest pest activity due to decreased tree resistance (Safranyik 2011), changes in the frequency and severity of forest fires due to changes in moisture levels of fuels and surface litter (de Groot et al. 2013), changes in the percentage of reforested sites that reach free-to-grow status, and changes in site productivity and forest land values (Johnston and Williamson 2005). In the future, other drought indices may also be developed to assess and project changes in moisture conditions in Canadian boreal forests. For example, Hogg et al. (2013) used the same precipitation and PET variables to create a simple soil moisture index (SMI) that proved remarkably successful in simulating observed changes in soil water content over a nine-year period at a mature aspen site in southern Saskatchewan. Similarly, Worrall et al. (2013) applied several moisture indices, including the Annual Dryness Index (ADI), to study aspen decline in both Canada and the USA.

This analysis was not intended as a full review of the options for adapting forest management to drought. For the purposes of illustration, examples of options to potentially mitigate the impacts of increased risk of drought include use of planting stock (species and provenances) that is more drought-tolerant, avoiding planting during periods of drought and accelerating planting during non-drought periods, promoting mixed and uneven-aged stands on sites vulnerable to drought, using silvicultural practices that conserve snow pack and soil moisture and reduce soil erosion, managing shade and shelter in regenerated stands, favouring mesic lowland sites over well-drained upland sites for plantations, and using "fire-smart" landscapes to reduce the spread of fires in dry periods.

\section{References}

Allen, C.D. et al. 2010. A global overview of drought and heatinduced tree mortality reveals emerging climate change risks for forests. For. Ecol. Manag. 259: 660-684.

Alley, W.M. 1984. The Palmer drought severity index: limitations and assumptions. J. Clim. Appl. Meteorol. 23: 1100-1109.

Brandt, J.P. 2009. The extent of the North American boreal zone. Environ. Rev. 17: 101-160. doi: 10.1139/A09-004.

[CCFM] Canadian Council of Forest Ministers. 2008. A vision for Canada's forest: 2008 and beyond [online]. Natural Resources Canada, Ottawa, ON. Available at http://ccfm.org/pdf/ Vision_EN.pdf [accessed 01-04-2012].

Dai, A. 2011. Drought under global warming: a review. Wiley Interdisciplinary Reviews: Clim. Chang. 2: 45-65.doi: 10.1002/wcc.81.

Dai, A., K.E. Trenberth and T. Qian. 2004. A global dataset of Palmer Drought Severity Index for 1870-2002: relationship with soil moisture and effects of surface warming. J. Hydrometeorol. 5: 1117-1130. 
de Groot, W.J., M.D. Flannigan and A.S. Cantin. 2013. Climate change impacts on future boreal fire regimes. For. Ecol. Manag. 294: 35-44. doi: 10.1016/j.foreco.2012.09.027.

Duinker, P. and L.A. Greig. 2007. Scenario analysis in environmental impacts assessment: improving explorations of the future. Environ. Impact Assess. Rev. 27: 206-219.

Edwards, J.E. and K.G. Hirsch. 2012. Adapting sustainable forest management to climate change: preparing for the future [online]. Canadian Council of Forest Ministers, Ottawa, ON. Available at http://ccfm.org/pdf/Edwards_PreparingForFuture_FinalEng.pdf [accessed 1 April 2014].

Gent, P.R. et al. 2011. The community climate system model version 4. J. Clim. 24: 4973-4991. doi: 10.1175/2011JCLI4083.1.

Gordon, H., S. O'Farrell, M. Collier, M. Dix, L. Rotstayn, E. Kowalczyk, T. Hirst and I. Watterson. 2010. The CSIRO Mk3.5 climate model. Cent. Aust. Weather Clim. Res. Tech. Rep. 021. Available at http://www.cawcr.gov.au/publications/technicalreports/ CTR_021.pdf [accessed 1 April 2014].

Henderson, N. E., E. Hogg, E. Barrow and B. Dolter. 2002. Climate change impacts on the island forests of the Great Plains and the implications for natural conservation policy. Prairie Adaptation Research Collaborative, Regina, SK.

Hogg, E.H. 1994. Climate and the southern limit of the western Canadian boreal forest. Can. J. For. Res. 24: 1835-1845. doi: 10.1139/x94-237.

Hogg, E.H. 1997. Temporal scaling of moisture and the forest-grassland boundary in western Canada. Agric. For. Meteorol. 84: 115-122. doi: 10.1016/S0168-1923(96)02380-5.

Hogg, E.H., A.G. Barr and T.A. Black. 2013. A simple soil moisture index for representing multi-year drought impacts on aspen productivity in the western Canadian interior. Agric. For. Meteorol. 178-179: 173-182. doi: 10.1016/j.agrformet.2013.04.025.

Hogg, E.H. and P.Y. Bernier. 2005. Climate change impacts on drought-prone forests in western Canada. For. Chron. 81: 675-682. doi: 10.5558/tfc81675-5.

Hogg, E.H., J.P. Brandt and B. Kochtubajda. 2005. Factors affecting interannual variation in growth of western Canadian boreal forests during 1951-2000. Can. J. For. Res. 35: 610-622. doi: 10.1139/X04-211.

Hogg, E.H., J.P. Brandt and M. Michaelian. 2008. Impacts of a regional drought on the productivity, dieback, and biomass of western Canadian aspen forest. Can. J. For. Res. 38: 1373-1384. doi: 10.1139/X08-001.

Hogg, E.H. and P.A. Hurdle. 1995. The aspen parkland in western Canada: a dry-climate analogue for the future boreal forest? Water Air Soil Pollut. 82: 391-400. doi: 10.1007\%2FBF01182849

Hogg, E.H. and A.G. Schwarz. 1997. Regeneration of planted conifer across climate moisture gradients on the Canadian prairies: implications for distribution and climate change. J. Biogeogr. 24: 527-534. doi: 10.1111/j.1365-2699.1997.00138.x.

Hutchinson, M.F. 1998. Interpolation of rainfall data with thin plate smoothing splines - part I: two dimensional smoothing of data with short range correlation. J. Geogr. Inf. Decis. Anal. 2: 139-151.

Hutchinson, M.F. 2006. ANUSPLIN version 4.36 user guide. Australian National University, Centre for Resource and Environmental Studies, Canberra, Australia.

[IPCC] Intergovernmental Panel on Climate Change. 2007. Climate change 2007: synthesis report. Contribution of Working Groups I, II and III to the fourth assessment report of the Intergovernmental Panel on Climate Change [Core Writing Team, R.K. Pachauri and A. Reisinger (eds.)]. Intergovernmental Panel on Climate Change, Geneva, Switzerland. 104 p. Available at http://www.ipcc.ch/publications_and_data/publications_ipcc_fourth _assessment_report_synthesis_report.htm [accessed 1 April 2014]. 2013. Climate change 2013: the physical science basis. Con-

tribution of Working Group I to the fifth assessment report of the Intergovernmental Panel on Climate Change [T.F. Stocker et al. (eds.)]. Cambridge Univ. Press, Cambridge, UK and New York, NY. Available at http://www.climatechange2013.org/images/report/ WG1AR5_ALL_FINAL.pdf [accessed 1 April 2014].

Johnston, M. and T. Williamson. 2005. Climate change implications for stand yields and soil expectation values: a northern Saskatchewan case study. For. Chron. 81(5): 683-690.

Johnston, M., T. Williamson, A. Munson, A. Ogden, M. Moroni, R. Parsons, D. Price and J. Stadt. 2010. Climate change and forest management in Canada: impacts, adaptive capacity and adaptation options. Sustainable Forest Management Network, Edmonton, AB. 54 p. Available at http://www.sfmn.ales.ualberta.ca/Publications/ $\sim /$ media/sfmn/Publications/StateofKnowledgeReports/Documents/SOK2010ClimateChangeJohnstonetalEn.ashx [accessed 1 April 2014].

Keyantash, J.D and J.A. Dracup. 2002. The quantification of drought: an evaluation of drought indices. Bull. Am. Met. Soc. 83:1167-1180.

Lowe, P.R. 1977. An approximating polynomial for computation of saturation vapor pressure. J. Appl. Meteorol. 16:100-103. doi: http://dx.doi.org/10.1175/1520-0450(1977)016<0100:AAPFTC > 2.0.CO;2.

Luo, Y. and H.Y.H. Chen. 2013. Observations from old forests underestimate climate change effects on tree mortality. Nat. Commun. 4: article 1655. doi: 10.1038/ncomms2681.

McFarlane, N.A., J.F. Scinocca, M. Lazare, R. Harvey, D. Verseghy and J. Li. 2005. The CCCma third generation atmospheric general circulation model. Environment Canada, Canadian Centre for Climate Modelling and Analysis, Victoria, BC. 25 p.

McKee, T.B., H.J. Doesken and J. Kleist. 1993. The relationship of drought frequency and duration of time scale. Eighth Conference on Applied Climatology, American Meteorological Society, Jan17-23, 1993, Anaheim CA, pp.179-186.

McKenney, D.W., J.H. Pedlar, M.F. Hutchinson, P. Papadopol, K. Lawrence, K. Campbell, E. Milewska, R.F. Hopkinson and D.T. Price. 2013. Spatial climate models for Canada's forestry community. For. Chron. 89(5): 659-663. doi: 10.5558/tfc2013-118.

McKenney, D.W., J.H. Pedlar, P. Papadopol and M.F. Hutchinson. 2006a. The development of 1901-2000 historical monthly climate models for Canada and the United States. Agric. For. Meteorol. 138: 69-81. doi: 10.1016/j.agrformet.2006.03.012.

McKenney, D.W., J.H. Pedlar, R.B. Rood and D. Price. 2011. Revisiting projected shifts in the climate envelopes of North American trees using updated general circulation models. Glob. Chang. Biol. 17(8): 2720-2730. doi: 10.1111/j.1365-2486.2011.02413.x.

McKenney, D., D. Price, P. Papadapol, M. Siltanen and K. Lawrence. 2006b. High-resolution climate change scenarios for North America. Tech. Note No. 107. Natural Resources Canada, Canadian Forest Service, Sault Ste. Marie, ON. Available at http://cfs.nrcan.gc.ca/pubwarehouse/pdfs/31503.pdf [accessed 1 April 2014].

Michaelian, M., E.H. Hogg, R.J. Hall and E. Arsenault. 2011. Massive mortality of aspen following severe drought along the southern edge of the Canadian boreal forest. Glob. Chang. Biol. 17: 2084-2094. doi: 10.1111/j.1365-2486.2010.02357.x.

Monteith, J.L. 1965. Evaporation and environment. 19th Symp. Soc. Exp. Biol., Univ. Press, Cambridge, UK. 19: 205-234.

Nakićenović, N. et al. 2000. Emissions scenarios. Cambridge University Press, Cambridge, UK and New York. 599 p. Available at http://www.ipcc.ch/ipccreports/sres/emission/index.php?idp $=0$ [accessed 1 April 2014].

Nigh, G.D. 2006. Impact of climate, moisture regime, and nutrient regime on the productivity of Douglas-fir in coastal British Columbia, Canada. Clim. Chang. 76: 321-337.

Nozawa, T., T. Nagashima, T. Ogura, T. Yokohata, N. Okada and H. Shiogama. 2007. Climate change simulations with a coupled ocean-atmosphere GCM called the Model for Interdisciplinary Research on Climate: MIROC3.2, CGER's supercomputer mono- 
graph report vol. 12. National Institute for Environmental Studies, Center for Global Environmental Research, Tsukuba, Japan.

Palmer, W.C. 1965. Meteorological drought. Res. Pap. No. 45. U.S. Weather Bureau, Washington, DC. Available at http:// www.ncdc.noaa.gov/temp-and-precip/drought/docs/palmer.pdf [accessed 1 April 2014].

Peng, C., Z. Ma, X. Lei, Q. Zhu, H. Chen, W. Wang, S. Liu, W. Li, $X$. Fang and $X$. Zhou. 2011. A drought-induced pervasive increase in tree mortality across Canada's boreal forests. Nat. Clim. Chang. 1: 467-471. doi: 10.1038/nclimate1293.

Price, D.T. and K.J. Isaac. 2012. Adapting sustainable forest management to climate change: scenarios for vulnerability assessment. Canadian Council of Forest Ministers, Ottawa, ON. Available at http://ccfm.org/pdf/PriceIsaac_Vulnerability_En.pdf [accessed 1 April 2014].

Price, D.T., D.W. McKenney, L.A. Joyce, R.M. Siltanen, P. Papadopol and K. Lawrence. 2011. High-resolution interpolation of climate scenarios for Canada derived from general circulation model simulations. Canadian Forest Service, Northern Forestry Centre, Edmonton, AB. Inf. Rep. NOR-X-421. Available at http://cfs.nrcan.gc.ca/pubwarehouse/pdfs/32971.pdf [accessed 1 April 2014].

Price, D.T., D.W. McKenney, I.A. Nalder, M.F. Hutchinson and J.L. Kesteven. 2000. A comparison of two statistical methods for spatial interpolation of Canadian monthly mean climate data. Agric. For. Meteorol. 101: 81-94. doi: 10.1016/S0168-1923(99)00169-0.

Price, D.T. et al. 2013. Anticipating the consequences of climate change for Canada's boreal forest ecosystems. Environ. Rev. 21: 322-365. DOI: 10.1139/er-2013-0042.

Randall, D.A. et al. 2007. Climate models and their evaluation. In S. Solomon, D. Qin, M. Manning, Z. Chen, M. Marquis, K.B. Averyt, M. Tignor and H.L. Miller (eds.). Climate change 2007: the physical science basis. Contribution of Working Group I to the fourth assessment report of the Intergovernmental Panel on Climate Change. pp. 589-662 Cambridge University Press, Cambridge, UK.

Safranyik, L. 2011. Development and survival of the spruce beetle, Dendroctonus rufipennis, in stumps and windthrow. Natural Resource Canada, Canadian Forest Service, Pacific Forestry Centre, Victoria, BC. Inf. Rep. BC-X-430.

Sauchyn, D.J. 2005. A 250-year climate and human history of prairie drought. In D.J. Sauchyn, M. Khandekar and E.R. Garnett (eds.). Proceedings of the Canadian Prairie Drought Workshop: The science, impacts and monitoring of drought in western Canada, Calgary, Alberta, 26-28 May 2004. pp. 27-30. University of Regina Press, Regina, SK.

Scinocca, J.F., N.A. McFarlane, M. Lazare, J. Li and D. Plummer. 2008. The CCCma third generation AGCM and its extension into the middle atmosphere. Atmos. Chem. Phys.8: 7055-7074.
Simpson, J.J., G.L. Huffford, C. Daly, J.S. Berg and M.D. Fleming. 2005. Comparing maps of mean monthly surface temperature and precipitation for Alaska and adjacent areas of Canada produced by two different methods. Arctic 58: 137-161.

Smith, J.B. and D.A Tirpak. 1989. Potential effects of global climate change on the United States. EPA-230-05-89-054. U.S. Environmental Protection Agency, Washington, DC.

Spittlehouse, D.L. 2005. Integrating climate change adaptation into forest management. For. Chron. 81: 91-95.

Spurr, S.H. and B.V. Barnes. 1980. Forest ecology. 3rd ed. John Wiley \& Sons, New York.

Thompson, I.D., M.D. Flannigan, B.M. Wotton and R. Suffling. 1996. The effect of climate change on landscape diversity: an example in Ontario forests. Environ. Monitor. Assess. 49: 213-233.

Thornthwaite, C.W. and B. Holzman. 1942. Measurement of evaporation from land and water surface. USDA Soil Conserv. Serv., Tech. Bull. 817. 143 p.

Trenberth, K.E., A. Dai, G. van der Schrier, P.D. Jones, J. Barichivich, K.R. Briffa and J. Sheffield. 2014. Global warming and changes in drought. Nature Clim. Chang. 4: 17-22.

Wahba, G. 1985. A comparison of GCV and GML for choosing the smoothing parameter in the generalized spline smoothing problem. Ann. Stat. 13: 1378-1402.

Watanabe, S., H. Miura, M. Sekiguchi, T. Nagashima, K. Sudo, S. Emori and M. Kawamiya. 2008. Development of an atmospheric general circulation model for intergraded earth system modelling on the earth simulator. J. Earth Simul. 9: 27-35.

Wells, N., S. Goddard and M.J. Hayes. 2004. A self-calibrating Palmer Drought Severity Index. J. Clim. 17: 2335-2351.

Williamson, T., S. Colombo, P. Duinker, P. Gray, R. Hennessey, D. Houle, M. Johnston, A. Ogden and D. Spittlehouse. 2009. Climate change and Canada's forest: from impacts to adaptation. Sustainable Forest Management Network and Natural Resources Canada, Canadian Forest Service, Northern Forestry Centre, Edmonton, AB. 104 p. Available at http://cfs.nrcan.gc.ca/pubwarehouse/pdfs/29616.pdf [accessed 1 April 2014].

Winnett, S.M. 1998. Potential effects of climate change on U.S. forests: a review. Clim. Res. 11: 39-49.

Worrall, J.J., G.E. Rehfeldt, A. Hamann, E.H. Hogg, S.B. Marchetti, M. Michaelian, and L.K. Gray. 2013. Recent declines of Populus tremuloides in North America linked to climate. For. Ecol. Manag. 299: 35-51.

Zoltai, S., T. Singh and M.J. Apps. 1991. Aspen in a changing climate. In S. Navratil and P.B. Chapman (eds.). Aspen management for the $21^{\text {st }}$ century. pp. 143-152. Forestry Canada, Northwest Region and Poplar Council of Canada, Edmonton, AB. Available at https://cfs.nrcan.gc.ca/publications?id=19159 [accessed 1 April 2014]. 